\title{
Pelatihan Pengolahan Limbah Pertanian dan Peternakan Pada Masyarakat Tani Ternak di Desa Tete Batu Kecamatan Sikur Kabupaten Lombok Timur
}

\author{
Dwi K. Purnamasari*, Syamsuhaidi, Tjokorda S. Binetra, Pardi, Sumiati, S. Sulastri \\ Fakultas Peternakan Universitas Mataram \\ Jl. Majapahit No. 62 Mataram 83125
}

\author{
Article history \\ Received: 04-09-2020 \\ Revised: 15-10-2020 \\ Accepted: 23-11-2020 \\ *Corresponding Author: \\ Dwi K. Purnamasari, \\ Fakultas Peternakan \\ Universitas Mataram, Mataram \\ Nusa Tenggara Barat, \\ Indonesia \\ Email: \\ emmadkp03@ygmail.com
}

\begin{abstract}
This activity is based on potensial of Tete Batu Village as agricultural area so that the availability of agricultural waste is abundant and so far it has not been used optimally as animal feed. Community service activities are carried out by providing materials on the technology of processing agricultural waste using various fermenters and local feed ingredients that can be used as alternative feed ingredients, then continuing the practice of processing livestock waste into liquid organic ferlizer and processing agricultural waste into silage. The service activity was attended by the Lombok Regional Government which involved in fostering livestock, head and management of Tete Batu, the livestock farming community, alumni and student, avarage 40 people. The community service activities have succeeded in increasing the knowledge and skills of breeders in processing livestock waste into liquid organic ferlizer which can be used to increase the fertility of agricultural plants and become products that can be sold so as to increase the income of the livestock farming community. Community service activities have resulted in good commitment from the livestock farming community, village administrators and related local government agencies to assist livestock farming communities in processing agricultural and livestock waste into useful products.
\end{abstract}

Keywords: fermentation; waste; liquid; organic fertizer; silage

Abtrak: Kegiatan ini didasarkan pada potensi Desa Tete Batu sebagai daerah pertanian yang subur sehingga ketersediaan limbah pertanian melimpah dan selama ini belum dimanfaatkan secara maksimal sebagai pakan ternak. Kegiatan pengabdian dilakukan melalui pemberian materi tentang teknologi mengolah limbah pertanian dengan menggunakan berbagai fermentor dan bahan-bahan pakan lokal yang bisa dijadikan sebagai bahan pakan alternative, lalu dilanjutkan praktik pengolahan limbah kotoran ternak menjadi Pupuk Organik Cair (POC) dan pengolahan limbah pertanian menjadi silase. Kegiatan pengabdian dihadiri Pemerintah Daerah Lombok Timur yang terkait dalam pembinaan peternakan, Kepala dan Pengurus Desa Tete Batu, masyarakat tani ternak, alumni dan mahasiswa, yang keseluruhan berjumlah \pm 40 orang. Kegiatan pengabdian berhasil meningkatkan pengetahuan dan keterampilan peternak dalam mengolah limbah peternakan menjadi POC yang dapat dimanfaatkan untuk meningkatkan kesuburan tanaman pertanian dan menjadi produk yang dapat dijual sehingga mampu meningkatkan penghasilan masyarakat tani ternak. Kegiatan pengabdian menghasilkan komitmen baik dari masyarakat tani ternak, pengurus desa dan instansi pemerintah daerah yang terkait untuk mendampingi usaha masyarakat tani ternak dalam mengolah limbah pertanian dan peternakan menjadi produk yang bermanfaat.

Kata Kunci: fermentasi; limbah; pupuk organic; cairan; silase 


\section{PENDAHULUAN}

Desa Tete Batu merupakan salah satu desa pemekaran dari desa induknya yaitu Kotaraja, Kotaraja sendiri pada saat itu dibagi dalam dua wilayah yakni Kotaraja Utara meliputi Tetebatu dan Kembang Kuning sementara Kota Raja Selatan terdiri dari Kota Raja dan Loyok. Pada tahun 1969, Tetebatu mekar menjadi desa tersendiri yang dipimpin oleh seorang Kepala Desa.

Potensi usaha peternakan di Desa Tetebatu, sebagian besar keluarga beternak sapi. Ternak sapi ini dianggap sebagai investasi atau sejenis tabungan keluarga. Ternak sapi ini bisa dikembangkan secara maksimal oleh masyarakat karena dari sisi keamanan sangat memungkinkan. Didukung dengan ketersediaan pakan ternak sendiri sangat mudah didapat. Pakan ternak yang dikembangkan jenis rumput gajah. Rumput gajah ditanam dengan memanfaatkan lahan di sekitar pinggir sungai, pematang sawah, pinggir jalan dan kebun, sedangkan untuk ternak kecil dikembangkan jenis ayam kampung dan bebek (Konsorsium ADBMI and Friends, 2019). Lebih lanjut dilaporkan Desa Tete Batu memiliki potensi yang besar pada bidang peternakan, dimana jumlah peternak sapi ada 300 orang dengan jumlah sapi 606 ekor, peternak ayam kampung 250 orang dengan jumlah ayam 1500 ekor, peternak itik 20 orang dengan jumlah itik 250 ekor, dan peternak ayam pedaging 15 orang dengan jumlah ayam 20.000 ekor. Namun demikian pengetahuan peternak dan masyarakat masih minim dalam mengelola limbah peternakan, sehingga bau kotoran seringkali dikeluhkan masyarakat

Berdasarkan hasil kajian dari Konsorsium ADBMI and Friends (2019), tantangan pengembangan usaha bidang peternakan (ayam, sapi, kambing, dan itik) yang harus dilakukan adalah

1. Untuk komoditas ayam, mahalnya harga pakan, pengolahan produk ayam dan limbah yang masih kurang dikarenakan minimnya pengetahuan masyarakat.

2. Untuk komoditas sapi, pengolahan produk sapi dan limbah kotoran sapi menjadi pupuk, bio gas, dan penol masih belum dilakukan, sehingga bau yang ditimbulkan terutama ketika musim hujan seringkali dikeluhkan masyarakat Selain itu belum adanya bibit unggul yang dimiliki masyarakat dan belum adanya bantuan pemerintah.

3. Untuk komuditas kambing, pengolahan produk kambing, pengolahan limbah kotoran, dan bantuan bibit unggul dari pemerintah belum ada.

4. Untuk komuditas itik, mahalnya harga pakan utama, peminat makan daging itik yang rendah dikarenakan minimnya pengetahuan masyarakat tentang pengolahan produk itik, keluhan masyarakat akibat lingkungan yang kotor dan bau yang ditimbulkan, serta biaya budidaya yang tinggi.

Berdasarkan permasalahan dan tantangan pengembangan tersebut, perlu dilakukan usaha pendampingan baik dari akademisi maupun dari pemerintah daerah setempat secara berkelanjutan, agar bidang peternakan semakin berkembang dan tidak menjadi usaha sampingan serta pendapatan masyarakat semakin meningkat. Saat ini kegiatan pengabdian yang utama dan menjadi prioritas untuk dilakukan adalah melatih masyarakat untuk menggunakan bahan pakan dari limbah pertanian melalui proses fermentasi dan pengolahan limbah peternakan menjadi produk-produk yang bermanfaat.

Fermentasi adalah proses pengubahan suatu senyawa komplek menjadi senyawa yang lebih sederhana menggunakan bantuan mikroorganisme baik dalam kondisi aerobik maupun anaerobik. Berdasarkan kadar substrat dan air, fermentasi dibagi menjadi dua tipe, yaitu fermentasi kultur terendam (kadar air sekitar 90\%) dan fermentasi substrat padat (kadar air $40-75 \%$ ). Proses fermentasi hasil samping tanaman perkebunan (bungkil inti sawit dan kelapa), tanaman pangan (dedak padi dan polard gandum), serta industri pertanian (kulit singkong, onggok, dari pabrik tapioca) untuk 
bahan pakan umumnya dilakukan dengan fermentasi substrat padat. Fermentasi substrat padat dinilai lebih baik karena volume proses fermentasi lebi rendah disbanding kultur terendam yang mengandung kadar air lebih tinggi (Stephanie dan Purwadaria, T., 2013).

Proses fermentasi bertujuan untuk meningkatkan protein dan menurunkan kadar serat kasar bahan pakan. Islamayati, dkk. (2010) melaporkan bahwa pada fermentasi ampas tahu menggunakan ragi tempe dengan level yang semakin tinggi mampu menurunkan kandungan serat kasar, yang disebabkan karena aktifitas mikroba menghasilkan selulase dan enzim lainnya yang mampu memecah ikatan kompleks serat kasar menjadi lebih sederhana. Zulkarnain dan Syahruddin (2008) melaporkan bahwa kiyambang yang difermentasi dengan Trichoderma harzianum sebesar $30 \%$ mampu meningkatkan kualitas nutrisi bahan pakan dan menurunkan kadar lemak abdominal ayam broiler. Purnamasari, dkk (2018) menghasilkan penelitian bahwa fermentasi daun eceng gondok menggunakan EM-4 mampu meningkatkan kualitas nutrisi daun eceng gondok dengan dosis terbaik 15\% dapat meningkatkan kadar protein kasar sebesar 4,34\%, menurunkan serat kasar sebesar 2,07\% dan meningkatkan kadar lemak kasar sebesar 1,57\%. Daun eceng gondok fermentasi memiliki potensi untuk dijadikan bahan pakan alternatif ternak unggas.

Selain itu dilakukan pengolahan limbah peternakan menjadi produk-produk yang bermanfaat dan dapat meningkatkan penghasilan petani peternak. Sebagai contoh produk yang dihasilkan dari pengolahan limbah adalah pupuk organik padat dan pupuk organik cair (POC). Pupuk organik cair sendiri merupakan salah satu pupuk organik yang berupa larutan dari hasil pembusukan bahan-bahan organik yang berasal dari sisa tanaman, kotoran hewan, dan manusia yang kandungan unsur haranya lebih dari satu unsur. Kegunaannya : memperbaiki sifat tanah, penyedia unsur hara, menekan populasi hama dan penyakit, mempercepat pertumbuhan (Putra, Y. dan Tarmizi, 2017). Azizi, Z, dkk., (2018) menggunakan media kotoran sapi, kambing, dan ayam sebagai media pembududayaan larva hermentia illucens, dan yang terbaik adalah media kotoran ayam. Media limbah kotoran ternak ini dapat digunakan sebagai media tumbuh untuk jenis larva lainnya, larva ini berfungsi sebagai decomposer limbah (Fauzi dan Sari, 2018).

Kegiatan pengabdian ini akan menjadi solusi dari permasalahan yang dialami peternak di Desa Tete Batu dan dapat menjadi peluang usaha untuk meningkatkan mata pencaharian masyarakat.

\section{METODE}

Kegiatan pengabdian masyarakat ini dilaksanakan dalam bentuk antara lain:

\section{Pelatihan I, pengolahan limbah pertanian dengan menggunakan fermentor EM4 menjadi silase.}

Fermentasi limbah pertanian di awali dengan memotong kecil - kecil dengan menggunakan pisau kemudian dijemur sampai beratnya konstan, setelah itu di masukkan ke dalam karung atau wadah lainnya. Sebelum dilakukan proses fermentasi dengan EM-4 peternakan dengan volume 1 liter yang mengandung Lactobacillus casei $1,5 \times 10^{6} \mathrm{cfu} / \mathrm{mL}$, Saccharomyces cerevisiae $1,5 \times 10^{6} \mathrm{cfu} / \mathrm{mL}$, dan Rhodopseudomonaspalustris $1,0 \times 10^{6} \mathrm{cfu} / \mathrm{mL}$, EM-4 terlebih dahulu diaktifkan yaitu dengan mencampurkan sebanyak $30 \mathrm{ml}$ EM-4 dengan $30 \mathrm{~g}$ molases sebagai nutrisi bakteri, kemudian ditambah aquadest steril sampai $1000 \mathrm{ml}$ dalam erlenmeyer. Lalu disimpan selama 24 jam dalam suhu ruangan $\left( \pm 27^{\circ} \mathrm{C}\right)$ dalam kondisi anaerob (Suryani, et al., 2017). Setelah siap dipakai, limbah pertanian dan starter EM-4 ditimbang dengan perbandingan sesuai dosis perlakuan yaitu: EM-4 $15 \%$ dari total bahan fermentasi sebanyak yang diinginkan. Masing - masing perlakuan di masukkan ke dalam 
kantung plastik atau wadah lainnya dan diaduk menggunakan tangan sampai semuanya tercampur rata kemudian diikat atau ditutup rapat sampai kedap udara setelah itu didiamkan selama 14 hari (2 minggu) dalam suhu ruangan agar terjadi proses fermentasi. Setelah 2 minggu kemudian pembungkus atau penutup dibuka untuk mengetahui proses fermentasi berhasil, dengan melihat perubahan warna dan bau khas fermentasi.

\section{Pelatihan Pengolahan Limbah Peternakan menjadi pupuk organik cair (POC)}

Alat dan bahan yang digunakan adalah tandon air, ember, karung, sekop, timbangan, corong, saringan, jerigen, kotoran sapi, EM4, molases dan air.

\section{Prosedur Kerja Pembuatan Pupuk cair}

1. Larutan EM4 dicampurkan dengan molases dalam satu wadah dan ditutup rapat dan didiamkan selama 24 jam.

2. Kotoran ternak sapi, sebanyak $50 \mathrm{~kg}$ dicampur dengan $20 \mathrm{~L}$ air ditempatkan dalam wadah ember, selanjutnya campuran diaduk hingga merata lalu disaring dengan saringan dan ditempatkan di dalam tandon. Hasil saringan dicampur dengan fermentasi molasses dengan EM4.

3. Selanjutnya tandon ditutup dan didiamkan selama 24 hari. Hasil saringan berupa POC dikontrol setiap minggu untuk memastikan keberhasilan dari proses fermentasi, apabila terdapat lumut putih, berbusa, dan mengeluarkan bau fermentasi maka dipastikan proses fermentasi berjalan dengan baik.

4. Setelah 24 hari POC dibuka kemudian ditempatkan dalam wadah kemasan 2 L kemudian diberi label dan siap untuk dipasarkan dan digunakan.

\section{HASIL DAN PEMBAHASAN}

Kegiatan pengabdian dihadiri oleh Pemerintah Daerah Kabupaten Lombok Timur khususnya dinas terkait dengan pembinaan masyarakat tani ternak, Kepala dan Pengurus Desa Tete Batu, masyarakat tani ternak, akademisi, alumni dan mahasiswa Fakultas Peternakan Universitas Mataram, yang keseluruhan berjumlah \pm 40 orang. Lokasi kegiatan di pusatkan di salah satu kediaman tokoh pemuda penggerak pembangunan Desa Tete Batu.

Kegiatan diawali dengan pemberian sambutan dari Pejabat Dinas Peternakan Kabupaten Lombok Timur, dilanjutkan dengan sambutan dari Kepala Desa, dan sambutan selanjutnya oleh Ketua Tim Pengabdian Fakultas Peternakan Universitas Mataram sekaligus pemberian materi pengolahan limbah pertanian dan peternakan menjadi pakan dan POC yang dapat dimanfaatkan dan dapat menambah penghasilan petani dan peternak Desa Tete Batu. Setelah pemberian materi berakhir, maka dilanjutkan sesi diskusi. Pada sesi diskusi, masyarakat antusias bertanya dan mengungkapkan berbagai permasalahan yang dialami, serta masyarakat semangat ingin mengetahui teknik pengolahan limbah pertanian dan peternakan menjadi silase dan POC yang selama ini masyarakat belum pernah melakukan. Kegiatan selanjutnya adalah praktik mengolah limbah pertanian dan peternakan menjadi silase dan POC.

Pembuatan silase menggunakan limbah jagung yang berupa kulit jagung, daun-daun kering yang banyak terkumpul di sekitar pekarangan, dan limbah-limbah tanaman pertanian lainnya. Limbah-limbah tersebut terlebih dahulu dipotong-potong menjadi ukuran yang lebih kecil dan hasil potongan diletakkan di atas terpal. Lalu campuran dedak sebagai sumber energi dibuat, dengan 
menambahkan molasses, EM4, dan yakult sebagai sumber bakteri selulolitik dan proteolitik, kemudian diaduk hingga merata. Setelah campuran dedak teraduk dengan merata, lalu dicampurkan pada limbah-limbah pertanian yang telah dipotong-potong hingga merata. Selanjutnya limbah pertanian di masukkan dalam plastic-plastik dan diikat hingga erat agar proses fermentasi berjalan secara anaerob yaitu tanpa oksigen selama 14 hari. Proses fermentasi berjalan dengan baik ditandai dengan hasil fermentasi setelah 14 hari akan tercium seperti bau tape. Selanjutnya silase dapat diberikan atau disimpan hingga 1 tahun sebagai cadangan pakan ketika musim kemarau.
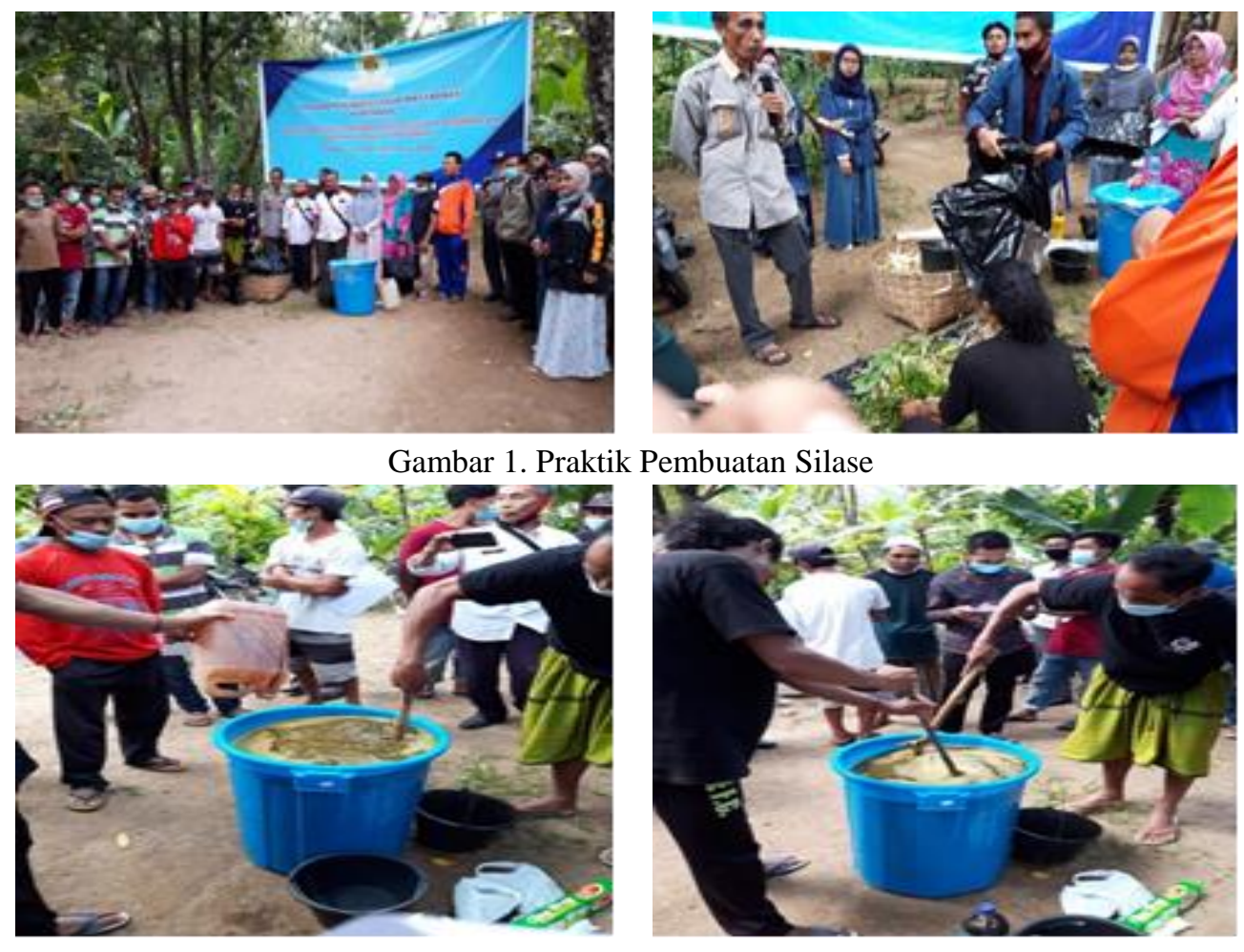

Gambar 2. Proses Pembuatan POC

Teknologi silase memungkinkan untuk mengolah bahan pakan hijauan untuk meningkatkan kecernaan dari bahan pakan yang pada umumnya mengandung serat kasar yang tinggi. Pengawetan bahan pakan dapat dilakukan dengan dua cara, yaitu dengan cara kering, yaitu pembuatan hijauan kering dan jerami kering dan cara basah, yakni melakukan fermentasi hijauan segar, misalnya rumput atau hasil samping pertanian, seperti jerami jagung (corn stover) dalam keadaan terkontrol yang dikenal dengan istilah pembuatan silase (Balai Pengkajian Teknologi Pertanian Aceh, 2016). Lebih lanjut dinyatakan, syarat hijauan yang dibuat silase adalah segala jenis tumbuhan atau hijauan serta bijian yang disukai oleh ternak, terutama yang mengandung banyak karbohidratnya dan mengandung kadar air lebih dari 50\%. McDonald et al. (1991) menyatakan bahwa silase merupakan bahan pakan yang diproduksi secara fermentasi, yaitu dengan cara pencapaian kondisi anaerob.

Silase dapat memaksimalkan feed intake dan mengurangi pencemaran udara. Proses fermentasi yang optimum pada silase juga dipengaruhi oleh lingkungan. Kualitas silase dipengaruhi oleh faktor biologi yaitu tahap kematangan bahan pakan juga teknologi yang dipergunakan saat pembuatan silase (Bolsen et al. 2000). Jika dibandingkan dengan pembuatan hay dan amoniasi, pembuatan silase memiliki kelebihan yaitu: hijauan tidak mudah rusak oleh hujan pada waktu dipanen, 
tidak banyak daun yang terbuang, silase umumnya lebih mudah dicerna dibandingkan hay dan amoniasi, dan karoten dalam hijauan lebih terjaga dibanding hay dan amoniasi.

Hasil penelitian Hanum, L., dkk (2019) bahwa pemberian silase pakan komplit berbahan dasar eceng gondok baik tanpa atau dengan penambahan starter L. plantarum menghasilkan protein tercerna yang sama dengan ransum konvensional (konsentrat dan rumput gajah). Naif, R., dkk (2015) meneliti kualitas nutrisi silase rumput gajah (Pennisetum purpureum) yang diberi dedak padi dan jagung giling dengan level berbeda menghasilkan bahwa pembuatan silase rumput gajah dengan kombinasi dedak padi $200 \mathrm{~g}$ ditambah jagung giling $200 \mathrm{~g}$ pada setiap $3 \mathrm{~kg}$ hijauan rumput gajah mampu memberikan hasil terbaik terhadap variabel kandungan protein kasar 12,61\% dan serat kasar sebesar 28,37\% sedangkan pada variabel kandungan bahan kering menunjukan nilai perlakuan yang relatif sama. Secara Umum dapat dikatakan bahwa pemberian dedak padi yang dikombinasikan dengan jagung giling pada pembuatan silase rumput gajah mampu mempertahankan nilai nutrisi kandungan rumput gajah.

Pembuatan POC, menggunakan limbah kotoran sapi yang ada di sekitar lokasi pengabdian sebanyak $20 \mathrm{~kg}$ ditampung menggunakan tendon lalu ditambahkan air sebanyak $20 \mathrm{~L}$. Larutan diaduk hingga merata, kemudian ditambahkan campuran EM4 dan molasses, lalu diaduk lagi hingga merata. Selanjutnya tendon ditutup rata hingga udara tidak masuk (anaerob). Proses fermentasi berlangsung selama 14 hari, setelah 14 hari tendon bisa dibuka, maka akan nampak bercak-bercak putih (jamur) pada permukaan larutan dan tercium bau aroma tape yang menandakan proses fermentasi berlangsung dengan baik. Lalu dilakukan penyaringan dan di masukkan ke dalam botol-botol kemasan dan selanjutnya POC bisa digunakan dan diperjualbelikan.

POC adalah pupuk yang tersedia dalam bentuk cair, POC dapat diartikan sebagai pupuk yang dibuat secara alami melalui proses fermentasi sehingga menghasilkan larutan hasil pembusukan dari sisa tanaman, maupun kotoran hewan atau manusia. Bagi sebagian orang pupuk organik cair lebih baik untuk digunakan karena terhindar dari bahan-bahan kimia/sintetis serta dampak yang baik bagi kesehatan. Pupuk organik cair terdiri dari mikroorganisme yang berperan penting dalam membantu pertumbuhan tanaman. POC terdapat berbagai jenis, tergantung dari kebutuhan. POC dapat dimanfaatkan dari tumbuhan, ataupun kotoran, diantaranya yang dapat dimanfaatkan adalah POC dari nasi basi, POC dari Sisa Sayur-Sayuran, POC dari kulit kakao dan POC dari kotoran hewan (Wikipedia, 2020).

Pupuk Organik Cair (POC) adalah pupuk berfasa cair yang dibuat dari bahan-bahan organik melalui proses pengomposan. Terdapat dua macam tipe pupuk organik cair yang dibuat melalui proses pengomposan. Pertama adalah POC yang dibuat dengan cara melarutkan pupuk organik yang telah jadi atau setengah jadi ke dalam air. Jenis pupuk yang dilarutkan bisa berupa pupuk hijau, pupuk kandang, pupuk kompos atau campuran semuanya. POC semacam ini karakteristiknya tidak jauh beda dengan pupuk organik padat, hanya saja wujudnya berupa cairan. Pupuk cair tipe ini suspensi larutannya kurang stabil dan mudah mengendap. Kita tidak bisa menyimpan pupuk tipe ini dalam jangka waktu lama. Setelah jadi biasanya harus langsung digunakan. Pengaplikasiannya dilakukan dengan cara menyiramkan pupuk pada permukaan tanah disekitar tanaman, tidak disemprotkan ke daun.

Kedua adalah (POC) yang dibuat dari bahan-bahan organik yang difermentasikan dalam kondisi anaerob dengan bantuan organisme hidup. Bahan bakunya dari material organik yang belum terkomposkan. Unsur hara yang terkandung dalam larutan pupuk cair tipe ini benar-benar berbentuk cair. Jadi larutannya lebih stabil bila dibiarkan tidak mengendap. Oleh karena itu, sifat dan 
karakteristiknya pun berbeda dengan POC yang dibuat dari pupuk padat yang dilarutkan ke dalam air (Priyowidodo, 2013).

Lebih lanjut dinyatakan, POC tidak bisa dijadikan pupuk utama dalam bercocok tanam. Sebaiknya gunakan pupuk organik padat sebagai pupuk utama/dasar. Pupuk organik padat akan tersimpan lebih lama dalam media tanam dan bisa menyediakan hara untuk jangka yang panjang, sedangkan, nutrisi yang ada pada pupuk cair lebih rentan terbawa erosi. Namun di sisi lain, lebih mudah dicerna oleh tanaman. Jenis pupuk cair lebih efektif dan efesien jika diaplikasikan pada daun, bunga dan batang dibanding pada media tanam (kecuali pada metode hidroponik). POC bisa berfungsi sebagai perangsang tumbuh. Terutama saat tanaman mulai bertunas atau saat perubahan dari fase vegetatif ke generatif untuk merangsang pertumbuhan buah dan biji. Daun dan batang bisa menyerap secara langsung pupuk yang diberikan melalui stomata atau pori-pori yang ada pada permukaannya. POC diaplikasikan pada daun, bunga atau batang, dengan cara mengencerkan pupuk dengan air bersih terlebih dahulu kemudian disemprotkan pada tanaman. Kepekatan pupuk organik cair yang akan disemprotkan tidak boleh lebih dari $2 \%$. Pada kebanyakan produk, pengenceran dilakukan hingga seratus kalinya. Artinya, setiap 1 liter pupuk diencerkan dengan 100 liter air (Wikipedia, 2020).

\section{KESIMPULAN DAN SARAN}

Kegiatan pengabdian berhasil meningkatkan pengetahuan dan keterampilan masyarakat tani ternak dalam mengolah limbah pertanian dan peternakan menjadi produk yang bermanfaat dan dapat meningkatkan kualitas hidup secara finansial. Kegiatan pengabdian selanjutnya sebaiknya mengikutsertakan istri-istri petani peternak agar program bisa dikerjakan secara bersama dalam satu keluarga.

\section{DAFTAR PUSTAKA}

Azizi, Z, D.K. Purnamasari, Syamsuhaidi, 2018. Penggunaan Berbagai Jenis Kotoran Ternak Terhadap pertumbuhan Dan Produksi Larva Hermentia illucens (Kajian Potensi Pakan Unggas). Jurnal Ilmu Dan Teknologi Peternakan Indonesia, vol. 4 (1); 224-230; Juli 2018.

Balai Tehnologi Pertanian Aceh, 2016. Pengawetan Hijauan Dengan Cara Silase Untuk Pakan Ternak Ruminansia. http://nad.litbang.pertanian.go.id/ (28 Agustus 2020).

Bolsen KK, Ashbell G, Wilkinson JM. 2000. Silage additives. New York. Basel. Cambridge. Tokyo: VCH. p 33-54.

Fauzi, R.U.A. dan E.R.N. Sari, 2018. Analisis Usaha Budidaya Maggot Sebagai Pakan Alternatif Pakan Lele. Jurnal Teknologi dan Manajemen Agroindustri; vol. 7, no. 1: hal 39-46.

Hanun, L., A. Muktiani, dan L.K. Nuswantara, 2019. Pengaruh penggunaan silase pakan komplit berbahan eceng gondok terhadap kecernaan protein pada domba. J. MEDIGRO. Vol. 15 No. 1, 2019 hal 12-19.

Islamayati R, Jamila, Hidayat AR., 2010. Nilai Nutrisi ampas Tahu Yang Difermentasi Dengan Berbagai Level Ragi Tempe. Artikel Ilmiah, Makasar: Fakultas Peternakan Universitas Hasanuddin.

Konsorsium ADMI and Friends, 2019. Analisis Ekonomi Dan Sejarah buruh Migran Desa Tete Batu Kecamatan sikur Kabupaten Lombok Timur.

McDonald P, Henderson AR, Heron SJE. 1991. The Biochemistry of Silage. Britain: Chalcombe Publication. 
Naif, R. , O. R. Nahak T. B b , A. A. Dethan, 2015. Kualitas Nutrisi Silase Rumput Gajah (Pennisetum purpureum) yang Diberi Dedak Padi dan Jagung Giling dengan Level Berbeda. Journal of Animal Science 1 (1) 6-8.

Priyowidodo, T., 2013. Cara Membuat Pupuk Organik Cair. https://alamtani.com/pupuk-organik-cair/ (31 Agustus 2020).

Purnamasari, D.K. dan M. Basri, 2018. Kajian Nutrisi Daun Eceng Gondok (Eichornia crassipes) yang Difermentasi dengan EM-4 dan Potensinya sebagai Pakan Unggas. Seminar Nasional Saintek, Lembaga Penelitian dan Pengabdian Pada Masyarakat, Universitas Mataram.

Putra, Y dan Tarmizi, 2017. Pembuatan Pupuk Organik Cair Berbahan Limbah Peternakan. Laporan Program Kewirausahaan. Fakultas Peternakan Universitas Mataram.

Stephanie dan Purwadaria, T., 2013. Fermentasi substrat Padat Kulit singkong Sebagai Bahan Pakan Ternak Unggas. Wartazoa Vol. 23 No. 1 Th. 2013 hlm 15 -22.

Suryani, Y., I. Hernaman dan Y. Jayanti, 2017. Pengaruh Pemberian Urea dan Sulfur pada Pembuatan Silase Limbah Padat Bioetanol yang Diberi Starter EM-4. Agripet Vol 17, No. 1, April 2017.

Wikipedia, 2020. Pupuk Organik Cair. https://id.wikipedia.org/wiki/Pupuk_organik_cair. (31 September 2020).

Zulkarnaen dan Syahruddin, E., 2008. Peningkatan Kualitas Kiyambang Salvinia molesta Melalui Pendekatan Bioteknologi Dengan Beberapa Jenis Kapang Srebagai Pakan Broiler. Laporan Penelitian Dosen Muda. Padang: Fakultas Peternakan universitas Andalas. 